\title{
Understanding child neglect in a gender context: a study performed in a Brazilian city*
}

\author{
Compreendendo a negligência infantil na perspectiva de \\ gênero: estudo em um município brasileiro \\ Comprendiendo la negligencia infantil desde la perspectiva \\ de género: estudio en un municipio brasileño
}

Emiko Yoshikawa Egry', Maíra Rosa Apostólico¹, Leda Maria Albuquerque², Rafaela Gessner³, Rosa Maria Godoy Serpa da Fonseca $^{1}$

* Extracted from the research project entitled "Instrumentalizando os profissionais da Atenção Básica para o enfrentamento da violência contra a criança”, Escola de Enfermagem, Universidade de São Paulo, 2014.

${ }^{1}$ Universidade de São Paulo, Escola de Enfermagem, Departamento de Enfermagem em Saúde Coletiva, São Paulo, SP, Brazil.

${ }^{2}$ Universidade de São Paulo, Escola de Enfermagem, Programa de Pós-Graduação em Enfermagem, São Paulo, SP, Brazil.

${ }^{3}$ Universidade de São Paulo, Escola de Enfermagem, Programa Interunidades de Doutoramento em Enfermagem, São Paulo, SP, Brazil.

\section{ABSTRACT}

Objective: To describe the phenomenon of child neglect and understand it in a gender context. Method: Retrospective, quantitative, and exploratory study that analyzed reports of violence by a child and adolescent protection network in a Brazilian city. The theoretical and methodological basis applied was TIPESC (Theory of Nursing Praxical Intervention in Collective Health), with a gender emphasis. Results: Neglect of children under the age of ten represents more than half the reports received over all the years studied; more boys than girls suffered neglect and $41.4 \%$ of the reports of neglect involved children under than age of three; women were identified as being solely responsible in $67.9 \%$, and as accessories in $17.3 \%$ of the incidents reported. Conclusion: Child neglect is a complex matter, the gender subordinate status inflicted on these children and their mothers who are responsible for their care underscore the social vulnerability of this group.

\section{DESCRIPTORS}

Negligence; Child Abuse; Domestic Violence; Gender Identity; Public Health Nursing. 


\section{INTRODUCTION}

Brazil has legal provisions protecting children and adolescents from all varieties of violence, including neglect. Among many other requirements, the 1988 Federal Brazilian Constitution most particularly governs rules on citizenship and personal dignity in order to promote the wellbeing of all, with no discrimination or age limit. Its text on the rights of citizens guarantees "education, health, nourishment, work, home, leisure, security, social security, maternity and child protection, and aid for the unprotected"(1).

Brazilian public policy relating to children and adolescents is protective and promotes healthy growth and development. The Child and Adolescent Statute, enacted in 1990, establishes that children and adolescents are entitled to all inherent human rights and must be guaranteed the means for their full development. Anyone who inflicts neglect upon, or any other offense against, the integrity of, children and adolescents, shall be penalized for such act or omission $^{(2)}$.

Brazil's National Policy for Morbidity and Mortality through Accident or Violence confers a material role upon the health sector to deal with these offenses, without prejudice to the liability of other sectors of society, and recommends joint action with a number of different social sectors $^{(3)}$.

In 2001, the city of Curitiba, capital of the State of Paraná, criated the Network for the Protection of Children and Adolescents at Risk of Violence. The network's regulations ${ }^{(4)}$, drawn up in 2004, established the types and nature of acts of violence against children and adolescents susceptible to confinement in municipal institutions. It defined the categories of violence as being interfamily violence (committed by a family member inside or outside the home), extrafamily violence (occurring outside the family circle, where the aggressor could be any individual), auto aggression (including suicide and conduct regarded as threatening to the individual's physical integrity), and fetal violence (committed by a pregnant woman against the fetus or by a third party against the pregnant woman with intent to harm the fetus). According to the Network Protocol, these categories are classified as follows: physical violence (non-accidental physical force which may or may not leave marks), sexual violence (sexual acts against the victim's will with the use of physical or psychological force), psychological violence (any act undermining self-esteem, characterized by disrespect, humiliation, and rejection), and neglect (omission of, or failure to provide for, the needs of the child, including abandonment and withholding of care) ${ }^{(4)}$.

Upon noting warning signs, health, education, and social assistance professionals fill out a warning notice and proceed to take action on the case. This action is based on integrated and intersector procedures for protection and prevention of violence, established in the Protocol. In addition to monitoring the victim, the family, and the aggressor in reported and confirmed cases, the Network also takes preventive actions, such as alerting the appropriate professionals and the community on the matter and applying strategies to ensure early intervention into the respective problem $^{(4)}$.

The Protocol states that failure to provide care within the home to meet the needs and care required by a child to ensure its satisfactory development results in neglect ${ }^{(4)}$. This could be the omission of care or ignorance of children's needs, influenced by cultural, social, and economic factors. It is a form of violence that is complicated to define and requires complex reflection regarding its determinants. Nevertheless, it is the most frequently reported form of violence in Brazil as in the global scenario ${ }^{(5)}$.

Child neglect occurs in the context of protection, health, education, and structural matters ${ }^{(4)}$. Deprivation of protection is the exposure of a child to risk. In the health context, the varieties of neglect include failure to attend prenatal and child-rearing appointments, in addition to failure to follow health treatments and other actions that undermine a child's health. Educational neglect includes disregard of school requirements, such as attending parent-teacher meetings, events, or other commitments that are part of the child's school life, failure to supervise school work, and absence from school.

Lastly, there is neglect arising from structural, economic, and social matters relating to the living conditions of the child and the family, but which are beyond their control ${ }^{(4)}$. If, on the one hand, interpersonal violence is more noticeable, since the identities of the victims and the aggressors are more clearly evident, in most cases, structural neglect is almost imperceptible, and, when it is recognized, it is difficult to identify the individual responsible ${ }^{(6)}$. The primary caregiver, i.e., the family, responsible for vocalizing and satisfying the child's needs shares its role as the party responsible for such neglect with the State. Thus, structural conditions do not exempt the family from its responsibility, although it needs the support of social service tools to reverse the existing state of neglect.

The many faces of neglect also include leaving the child at home or in the street without the presence of a responsible adult, in addition to the absence of care involving hygiene, feeding, safety, among others ${ }^{(4)}$. Accordingly, this characterization shows that, in cases of neglect, the nature of the respective violence is inextricably associated with the difficulty, or impossibility, of directly caring for the child and meeting his/her needs. This could be due to structural reasons, deficit of ability, or parental behavior ${ }^{(5)}$. Several types of neglect can be simultaneously recorded in the official report.

Other forms of violence are even more critical, such as physical and, above all, sexual, violence. However, the constant existence of child neglect is responsible for major damage to the victim's physical, emotional, and social development. Neglect is associated with the increase of child death, exposure to other forms of violence, and restricted new social relationship experiences, both in the family and in the community environment ${ }^{(5)}$. The consequences of neglect can persist for many years, and have a devastating impact on child development, some of them even graver than those arising from physical violence. Thus, a policy of 
attaching greater importance to physical violence against children risks disregarding the real evil arising from neglect, which is harder to recognize given its subjective nature ${ }^{(7)}$.

Historically, women have always been in charge of the private space. In addition to bearing and rearing children, maternity includes the full care of the child during its first years of life. Although, nowadays we see gradual changes standards for the male sex, men still hold relatively little responsibility for their children. This is especially evident in care activities such as feeding, hygiene, safety, monitoring school life and health, among others. Men are still, in theory, at least, responsible for financially maintaining the home and family. But, at the same time, women now occupy a greater public space such as the work force, for personal realization reasons, the need to contribute to the family income, or both ${ }^{(8)}$. This concept becomes replicated in the family environment in relations and also in services, such as schools, health centers, among other, perpetuating and prioritizing the woman's responsibility in the private space and that of men in the public space.

Given that family relationships inevitably involve inequalities of power, including the gender of power, and that child neglect occurs in this space ${ }^{(9)}$, the question arises: how does this gender category explain neglect in the domestic environment?

Gender can be defined as the constituting factor of social relations based on the perceived differences between the sexes, in the processes of socializing men and women. This factor enables us to understand the female and male social constructions, as socially established for men and women. Gender analysis reveals the disproportionate nature of the exercise of power, where, as a rule, women occupy subordinate and secondary positions in relation to $\operatorname{men}^{(10)}$.

Based on the above, the aim of this study is to characterize the phenomenon of child neglect and to understand it in a gender context. The end purpose was to support health related actions, especially those of the Nursing Profession, to prevent and confront the problem.

\section{METHOD}

This is an exploratory, retrospective, and descriptive study. It utilized violence report data obtained from the Curitiba Network for the Protection of Children and Adolescents at Risk of Violence.

The theoretical and methodological basis applied was TIPESC (Theory of Nursing Praxical Intervention in Collective Health) ${ }^{(11)}$ and the analytical gender category was selected due to its potential for explaining power relations between men and women, men and men, and women and women $^{(10)}$. Accordingly, the gender approach sought to clarify the relationship between the following variables: sex and age of the child, sex of the principal aggressor, and relationship of the aggressor to the child. These variables are present in the Protection Network's violence against children report files.

The data for 2004 to 2012 were collated in January 2013. An analysis was carried out on the reports on cases of suspected or confirmed domestic violence, specifically, cases of neglect involving children under the age of ten, living in the city of Curitiba. The data were exportedas Excel spreadsheets to the Protection Network database and a descriptive statistics analysis carried out.

Over the period analyzed, 37,221 reports of suspected or confirmed cases of violence against children and adolescents were registered, and these represented the universe of the present study. It should be noted that the Protection Network also reports cases of violence against pregnant women, which apply in the fetal violence context. Of the total reports, 28,263 (75.93\%) relate to domestic violence against children living in Curitiba, of whom 19,257 (51.73\%) were neglected. Of these, 11,811 (31.73\%) represented reports of domestic violence involving children under the age of ten, living in Curitiba, the sample analyzed in this study. In the case of some of the variables, the total differed due to the non-completion of all data in the report form.

Reports relating to other types of violence (outside the family, fetal, and self harming) and of other forms (physical, sexual, psychological, and abandonment) were excluded, as were 61 records which did not state the age of the child in question.

Some results relating to children under three were highlighted. This emphasis was due to the importance to early infancy of growth and infant development, and the repercussions when these stages are compromised by violence, in childhood and adult life, and for the community as a whole.

This study is part of a research project entitled, Enabling Basic Attention Professionals to Engage with Violence against Children, financed by FAPESP (Foundation for Support of Research in the State of São Paulo), Fundação Maria Cecília Souto Vidigal (Cases 2011/50.932-1 and 2012/067142). It was approved by the Ethics Committee for Research by the Nursing Faculty of USP (University of São Paulo), via $C A A E$ (Certificate of Presentation for Ethical Consideration) No. 02153012.9.0000.5392.

Also, in the context of this study, it is worth noting that, in 2010, Curitiba attained tenth place in the Brazilian ranking of the HDI (Human Development Index). This covered its population of $1,751,907$ inhabitants, almost 220,000 of whom were children under the age of ten ${ }^{(12)}$. Households headed by women represented $41.46 \%$ of the city's population, a percentage greater than that of the state of Paraná $(35.64 \%)$ and of Brazil itself $(38.74 \%)^{(13)}$.

\section{RESULTS}

Over half the neglect cases reported involved children under the age of ten. In 2010, the ratio was five neglect reports to every 100 children in this age group. The distribution of reports by age of the children is shown in Table 1 below.

Of the reports of neglect recorded for the period $($ no $=11,811), 4,887(41.4 \%)$ related to children under the age of five, while 3,222 (27.3\%) applied to children of less than one year, the group most affected by neglect when compared with children of other ages.

Cases of sexual abuse showed more reports involving boys (57.3\%), particularly from the age of six onwards (Fig- 
ure 1). It should be noted that, in 107 (0.9\%) reports of neglect involving newborns, the sex of the child was not disclosed. Accordingly, these reports were not considered in this figure since the group of victims under the age of one was removed.

Table 1 - Distribution of reports of neglect of children under the age of ten by age of child, from 2004 through 2012 - Curitiba, PR, Brazil, 2013.

\begin{tabular}{ccc}
\hline Age in years & No. & \% \\
\hline under 1 & 3,222 & 27.3 \\
1 & 973 & 8.2 \\
2 & 692 & 5.9 \\
3 & 604 & 5.1 \\
4 & 640 & 5.4 \\
5 & 672 & 5.7 \\
6 & 916 & 7.8 \\
7 & 1,121 & 9.5 \\
8 & 1,455 & 12.3 \\
9 & 1,516 & 12.8 \\
\hline Total & $\mathbf{1 1 , 8 1 1}$ & $\mathbf{1 0 0 . 0}$ \\
\hline
\end{tabular}

Source: Database of the Protection Network for Children and Adolescents at Risk of Violence in Curitiba. Municipal Health Secretariat of Curitiba, PR, Brazil, 2013. 1800

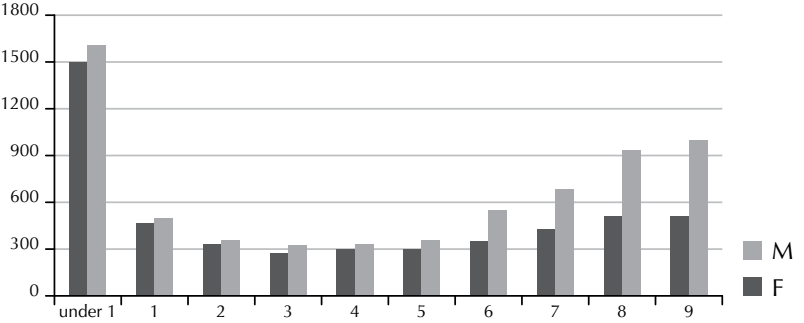

Figure 1 - Distribution of reports of neglect by victim's age and sex, from 2004 through 2012 - Curitiba, PR, Brazil, 2013.

Source: Database of the Protection Network for Children and Adolescents at Risk of Violence in Curitiba. Municipal Health Secretariat of Curitiba, PR, Brazil, 2013.

This type of neglect was stated in 10,794 (total of 91.3\%) reports, with the simultaneous occurrence of more than one type of neglect (Table 2).

Further to the ratio of type of neglect to age of child, it was specifically noted that, in the case of children under the age of three, the reports of neglect related to Health and Protection, while, for children over three, health neglect gave way to education neglect.

The child sex variable, in respect of the type of neglect, showed percentages close to an overall proportion of 57.3\% for boys and $42.7 \%$ for girls, with the exception of the Health-Education neglect and Health-Education-Protection neglect, where boys represented $70.8 \%$ and $70.4 \%$ of the cases, respectively.

It has been found that the reason for the sex abuse observed in children remained related to the sex of the aggressor, thereby underlining that neglect impacts both sexes at a rate similar to the overall panorama, regardless of whether the aggressor is male or female. Women tended more frequently to be identified as the parties responsible for neglect of children under the age of ten, in
$7,937(67.9 \%)$ of the reports, followed by both sexes as responsible at a total of 2,028 (17.3\%), and only men in 1,731 (14.8\%) cases. Another 115 (0.9\%) reports lacked this information.

Table 2 - Distribution of reports of neglect of children under the age of ten, by age, from 2004 through 2012 - Curitiba, PR, Brazil, 2013.

\begin{tabular}{|c|c|c|c|c|c|c|}
\hline \multirow{2}{*}{ Type of neglect } & \multicolumn{2}{|c|}{ Under 3} & \multicolumn{2}{|c|}{3 to 9} & \multicolumn{2}{|c|}{ Total } \\
\hline & No. & $\%$ & No. & $\%$ & No. & $\%$ \\
\hline Health-Protection & 2498 & 23.1 & 1277 & 11.8 & 3775 & 35.0 \\
\hline Protection & 1177 & 10.9 & 1641 & 15.2 & 2818 & 26.1 \\
\hline Education & 3 & 0.0 & 826 & 7.7 & 829 & 7.7 \\
\hline Health & 325 & 3.0 & 429 & 4.0 & 754 & 7.0 \\
\hline Health-Education & 7 & 0.1 & 605 & 5.6 & 612 & 5.7 \\
\hline $\begin{array}{l}\text { Education- } \\
\text { Protection }\end{array}$ & 9 & 0.1 & 476 & 4.4 & 485 & 4.5 \\
\hline $\begin{array}{l}\text { Health-Protection- } \\
\text { Structural }\end{array}$ & 252 & 2.3 & 164 & 1.5 & 416 & 3.9 \\
\hline $\begin{array}{l}\text { Health-Education- } \\
\text { Protection }\end{array}$ & 13 & 0.1 & 393 & 3.6 & 406 & 3.8 \\
\hline Protection-Structural & 105 & 1.0 & 165 & 1.5 & 270 & 2.5 \\
\hline $\begin{array}{l}\text { Health-Education- } \\
\text { Protection-Structural }\end{array}$ & 8 & 0.1 & 111 & 1.0 & 119 & 1.1 \\
\hline Structural & 54 & 0.5 & 52 & 0.5 & 106 & 1.0 \\
\hline Health-Structural & 31 & 0.3 & 42 & 0.4 & 73 & 0.7 \\
\hline $\begin{array}{l}\text { Education- } \\
\text { Protection-Structural }\end{array}$ & 3 & 0.0 & 62 & 0.6 & 65 & 0.6 \\
\hline Education-Structural & 0 & 0.0 & 42 & 0.4 & 42 & 0.4 \\
\hline $\begin{array}{l}\text { Health-Education- } \\
\text { Structural }\end{array}$ & 2 & 0.0 & 22 & 0.2 & 24 & 0.2 \\
\hline Total & 4487 & 41.6 & 6307 & 58.4 & 10794 & 100.0 \\
\hline
\end{tabular}

Source: Database of the Protection Network for Children and Adolescents at Risk of Violence in Curitiba. Municipal Health Secretariat of Curitiba, PR, Brazil, 2013.

An analysis of the age distribution of the children showed that, the younger the child, the greater likelihood of the woman's responsibility (Figure 2).

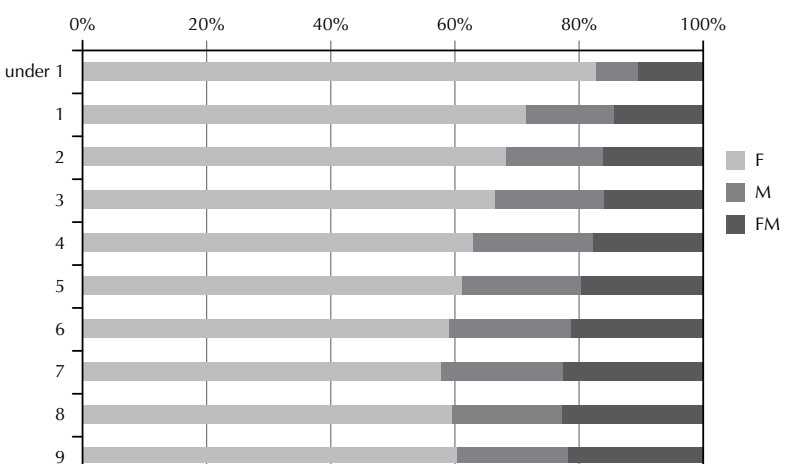

Figure 2 - Distribution of the reports of neglect of children under ten, by sex of the aggressor and age of the child in years, from 2004 through 2012 - Curitiba, PR, Brazil, 2013 (No.=11,696).

Source: Database of the Protection Network for Children and Adolescents at Risk of Violence in Curitiba. Municipal Health Secretariat of Curitiba, PR, Brazil, 2013.

The reports holding women accountable increased over the period under study, while those impugning men decreased. Only as from 2008, did the Report File record the parent combination, indicating the possibility of both parents being responsible for violence against children. 
Further to the family relationship between the aggressor and child, in 7,568 (64.1\%) of the neglect cases reported, the mother was held responsible, the father in 1,573 $(13.3 \%)$ cases, and both parents in 1,977 (16.3\%) cases. Of the remainder $(693-5.8 \%)$, the individuals responsible were unknown, names not given, or other, such as grandparents, aunts, and uncles, 369 (53.2\%) of whom were of the female sex.

Of the reports on types of neglect based on the sex of the aggressor, 10,687 (90.48\% of the total) reports were analyzed, and contained both data. Women ranked as chiefly responsible in all types of neglect and, frequently, more than one type of neglect was reported, as shown in Table 3 below.

Table 3 - Distribution of the reports by type of neglect of children under ten, by sex of the aggressor, from 2004 through 2012 - Curitiba, PR, Brazil, 2013.

\begin{tabular}{lcccc}
\hline $\begin{array}{l}\text { Type of } \\
\text { neglect }\end{array}$ & $\begin{array}{c}\text { Women } \\
\text { No. }(\%)\end{array}$ & $\begin{array}{c}\text { Men } \\
\text { No. }(\%)\end{array}$ & $\begin{array}{c}\text { Both } \\
\text { No. }(\%)\end{array}$ & Total \\
\hline Education & 1,448 & 342 & 782 & 2,572 \\
& $(56.3 \%)$ & $(13.3 \%)$ & $(30.4 \%)$ & \\
Health & 4,280 & 640 & 1,212 & 6,132 \\
& $(69.8 \%)$ & $(10.4 \%)$ & $(19.8 \%)$ & \\
Protection & 5,692 & 1,205 & 1,377 & 8,274 \\
& $(68.8 \%)$ & $(14.6 \%)$ & $(16.7 \%)$ & \\
Structural & 686 & 161 & 233 & 1,080 \\
\hline
\end{tabular}

Source: Database of the Protection Network for Children and Adolescents at Risk of Violence in Curitiba. Municipal Health Secretariat of Curitiba, PR, Brazil, 2013.

\section{DISCUSSION}

The results presented showed that children of both sexes are victims of neglect. However, a difference was noted in the absolute number of reports in respect of this variable. The gender distinction relates to the many natures of violence. If, on the one hand, fewer girls are victims of neglect but more suffer from very serious types of violence, boys receive the imposition of social standards such as an expression of force, power, and dominance. Accordingly, they are more exposed to ill-treatment, such as repeated neglect and are also forced to submit to subterfuge, banalization, and the concept of the normalcy of other forms of violence that challenge the social role of men and their masculinity ${ }^{(9-14)}$.

On the other hand, and this has been confirmed by other authors ${ }^{(8-9)}$, the discrepancy between the percentage of men and women held liable for neglect can be explained by the difference in their living conditions. This includes the attribution of socially and historically constructed group and family roles, resulting in differing degrees of responsibility in relation to child care. Thus, the gender matrix, constructed both socially and historically, explains the differences in the nature of the aggressors in relation to child neglect.

The substantial increase in socially imposed consumption has altered the profile of family expenditures and, accordingly, the demand for greater family income ${ }^{(8)}$. The changed structure of families, where women increasingly enter the job market or, even, head families, has produced new approaches to child rearing ${ }^{(15)}$.
Now, in addition to representing a means of obtaining financial resources, for women paid work, inside or outside the house, represents a potential for self realization and the acquisition of social skills ${ }^{(15)}$. In the area of personal realization, the domestic universe reserved for them until little more than half a century ago is not enough; they want to fly higher and achieve personal realization. In addition to more education and citizen's autonomy, paid productive work has become a sine qua non for life in our society ${ }^{(8)}$.

The great contradiction here is that, unlike shared responsibility in the division of work in all areas, domestic work is still regarded as naturally being a feminine task. The situation becomes increasingly exacerbated in the absence of aspouse or partner, a circumstance where women take on all domestic and productive tasks, which can only negatively impact their performance in the maternal area, and in their care of the house and family.

Even in the workplace, women are more subject to subordinate roles than men. This can be perceived in undervalued work arising from low qualifications and social devaluation, and the lack of consumer goods and services to provide some support for their services. Unequal gender relations heighten the inequalities associated with social classes and generations. The precarious social position experienced by women hinders their attempts to achieve satisfactory conditions of life for themselves and also for their children ${ }^{(16)}$. This is due to the reduced availability of places in social organizations such as daycares or other institutions that take in children during the working hours of the family adults. The existence of crèches should not just be regarded as a resource to facilitate women's lives, but as space providing care, education, and upholding the welfare of children.

A study carried out in Portugal shows that work provides a slight protection in relation to violence against children. However, a precarious bond, dissatisfaction with work, or professional instability has more negative impacts, since they raise stress levels and undermine the exercising of parental roles, especially in relation to neglect. Unstable economic and social conditions are not direct neglect determinants, but they are known to undermine the likelihoods of insertion into higher qualification employment, thereby further contributing to dissatisfaction and threatening relationships between mothers, fathers, and children ${ }^{(15)}$.

Our study showed that types of neglect vary in accordance with the age of the child. Neglect of health is reported more commonly for children under three, while educational neglect is more frequent in the case of older children. Despite the fact that the process of insertion into the social spaces of health care and education alters according to a child's growth cycle, women remain doomed to the inescapable role of child carer, all too frequently, without the due involvement of the man or the rest of the family, even though these circumstances are reinforced by the attitude of the social services.

By placing responsibility for child care on mothers, society requires time and dedication from women, without 
entering into the responsibility of the father figure, an individual who is frequently absent from the scene. Even in cases of a father present in the family, schools tend to insist only on the presence of the woman-mother at parentteacher meetings, and her absence is regarded as a sign of neglect. The attitude of the health service is similar since it expects that the woman will be solely responsible for being present at monitoring meetings, and at healthcare monitoring meetings, continuation of treatment, and general healthcare issues ${ }^{(17)}$.

This model reproduces an outdated reality from a time when women worked only in the home, cared for their children, and were rarely involved in professional activities outside the home. The ever greater presence of women in the labor market, regardless of whether for emancipation reasons, or for the need to survive, has transformed the older reality into a panorama of unavailable social support with the gravest of consequences for children, families, and society as a whole.

On examining the phenomenon of gender based violence, the health sector and others, tend to change the dominant perception that reinforces the idealized view of woman-mother at the service of the family ${ }^{(17)}$. Violence and, above all, child neglect must be treated as social and political problems. The health sector takes the most action, but this confrontation with the problem is not its exclusive responsibility. What is needed is an intersector, multiprofessional, and interdisciplinary approach extrapolating the biological dimension and building a social support network, in addition to collaboration with the community ${ }^{(18)}$.

The difficulty attached to identifying neglect in a family context shows the need for professional work with families. Proximity and familiarity with differing family dynamics, considering culture, economic position, and, most importantly, gender relationships favor the identification of these cases and the transformation of their determinants. The work of Basic Attention professionals is particularly advantaged here ${ }^{(14)}$. This approach also requires an understanding of women's ways of producing and living, i.e., how they become inserted into production and reproduction processes in both work and family life, thereby identifying the vulnerabilities and needs common to their social group.

Violence reports are a recent strategy in Brazil, and little is known about how this operates. Similarly, data visibility is also minimal, despite being recognized as a startup means. It requires a group of organized political, legal, social, and ethical actions ${ }^{(19)}$, such as those in contexts that seek group confrontation.

A study carried out with dentists in Saudi Arabia on the knowledge, attitudes, and experience of these professionals, showed that, despite their expertise in their profession and the fact that they had been present at accounts of child neglect, very few reported these events. The reasons they failed to file a report varied from fear of reprisals by the family, insecurity in relation to the violence diagnosis, to uncertainty as how to handle the case ${ }^{(20)}$. This is where group work is so important, where the responsibil- ity for filing a report is no longer in the hands of the professional but those of the institution, which should then commence monitoring the child and the family, notify, and directly intervene, such as in health education.

As this study has shown, if the phenomenon of child neglect is not publicized in an important context such as gender, it will remain impossible to identify the more vulnerable social groups and, thus, the more urgent targets for clearly articulated public policy and related specificity. There is little point in prescribing gender solutions for different social groups, since this leads to a waste of projects, programs, and actions. Reporting is a powerful tool enabling visibility in cases of violence, but its interpretation must be both cautious and critical, to avoid blaming innocent victims.

According to TIPESC (11) theory, some immediate action possibilities exist, via examining the reality of violence against children and public policy for confronting it. This should be based on an ethical and political perspective aimed at understanding violence as a social and multifaceted phenomenon. For this, a critical study of the vulnerabilities in this territory and the families therein is crucial. It should include their strengths and weaknesses, in addition to the construction of strategies and transformation of this reality via insectorial actions in conjunction with the tools currently in place.

The application of the gender context will enable a review of the stereotypes that place the burden of neglect on the mother, thereby redistributing the responsibility to guarantee the rights of children to the family and the community.

The National Policy for Morbidity and Mortality Reduction by Accident and Violence in Brazil was enacted to meet the Brazilian people's demand for the end of violence. However, no mechanisms have been introduced to act on the social determinants of violence. Despite considerable advances, there are many obstacles to be overcome, such as desegregation of networks and fragmentation of appropriate actions ${ }^{(21)}$.

Brazilian social policies are still aimed at specific segments of society - the poor, the marginalized, and the needy. They select, stigmatize, segment, and label poor families, and the action they take is contrary to the recognition of social rights, respect for dignity, life, the body, and overall development ${ }^{(22)}$. This directioning reinforces neoliberal ideas of assistance to the poor and the consolidation of capitalism as a means of production and as a life model imposed upon the population. It exempts the State from enacting consistent policies to add value to the rights and autonomy of individuals.

Curitiba's public health policies are exemplary in the areas of sector articulation and the organization of its social assistance, management, and data information services. These are highly sought after by the general public and this is clearly reflected in its morbidity and mortality rates. However, we must remember that many health programs are run on a risk criterion basis: this is insufficient to enable the authorities to identify the health needs of the general public ${ }^{(23)}$ or to tackle a problem as complex as violence against children. 
Confronting these problems requires the formation of networks, since the health sector alone cannot handle such a complex problem, one involving determinants in the different areas of its victims' lives. It is essential that the State fulfill its role as guarantor of rights, including identifying ways to overcome violence.

A critical and reality based gender balanced professional training education based on aspects of reality is absolutely key to the construction of strategies for eradicating neglect. Additionally, social, health, and education services, support networks, and social support are essential to prevail over the negative experience of individuals exposed to violence $^{(15)}$. This is because they form multiple healthy interpersonal relationship spaces. The presence of the health professional is crucial to demanding the presence and positive action of the State, in view of its limited connection with this territory.

This study presents the limitations of failure to explore the generation category, since this area also deals with social and family relationships involving different generation groups: the child, the adolescent, the adult, and the senior citizen $^{(24-25)}$. Subsequent studies covering these two categories are essential.

\section{CONCLUSION}

This study evidences the phenomenon of child neglect in a gender context, duly recorded based on the data of the Curitiba Protection Network. It clearly shows that boys suffer more neglect than girls and that women (mothers or carers) are chiefly responsible, particularly in cases of neglect involving health and education. The subordinate status of women is underscored by their sole responsibility for their children, a situation exacerbated by the absence of the father figure. Added to this is their sense of guilt for not meeting the children's need for subsistence, assistance, care, and monitored child development, and their precarious living and working conditions. All of these represent highly unfavorable conditions for carrying out the duties of good maternal care. This is equally valid both for women who work outside the home and for those who do not work. They are judged on the erroneous assumption that the maternity function comes naturally to mothers. Society criticizes them without verifying these mothers' background, in terms of social class, level of education, and others, including their social attributes as the degree of knowledge required to satisfactorily rear children, and absolves the State of all and any social responsibility.

\section{RESUMO}

Objetivo: Caracterizar o fenômeno da negligência infantil e compreendê-lo na perspectiva de gênero. Método: Estudo retrospectivo, quantitativo e exploratório que analisou oito anos de notificação de violência de uma rede de proteção à criança e ao adolescente de uma cidade brasileira. A base teórico-metodológica foi a TIPESC, privilegiando a categoria gênero. Resultados: A negligência com crianças menores de dez anos constituiu mais da metade das notificações em todos os anos estudados; os meninos foram os mais negligenciados e 41,4\% das notificações de negligência eram de menores de três anos; a mulher foi apontada como a única responsável em $67,9 \%$ e coparticipante em 17,3\% das notificações de negligência. Conclusão: A negligência infantil é um fenômeno complexo e a subalternidade de gênero a que estão submetidas as crianças e as mães responsáveis pelo cuidado denota a vulnerabilidade social deste grupo.

\section{DESCRITORES}

Negligência; Maus-Tratos Infantis; Violência Doméstica; Identidade de Gênero; Enfermagem em Saúde Pública.

\section{RESUMEN}

Objetivo: Caracterizar el fenómeno de la negligencia infantil y comprenderlo desde la perspectiva de género. Método: Estudio retrospectivo, cuantitativo y exploratorio que analizó ocho años de notificación de violencia de una red de protección al niño y al adolescente de una ciudad brasileña. La base teórico-metodológica fue la TIPESC, privilegiando la categoría género. Resultados: La negligencia con niños menores de diez años constituyó más de la mitad de las notificaciones en todos los años estudiados; los niños fueron los que más sufrieron negligencia y el $41,4 \%$ de las notificaciones de negligencia eran de menores de tres años; la mujer fue señalada como la única responsable en el 67,9\% y coparticipante en el 17,3\% de las notificaciones de negligencia. Conclusión: La negligencia infantil es un fenómeno complejo y la subalternidad de género a que están sometidos los niños y las madres responsables del cuidado denota la vulnerabilidad social de ese grupo.

\section{DESCRIPTORES}

Negligencia; Maltrato a los Niños; Violencia Doméstica; Identidad de Género; Enfermería em Salud Pública.

\section{REFERENCES}

1. Brasil. Constituição, 1988. Constituição da República Federativa do Brasil [Internet]. Brasília; 1988 [citado 2015 fev. 10]. Disponível em: http://www.planalto.gov.br/ccivil_03/constituicao/constituicao.htm

2. Brasil. Lei No 8.069, de 13 de julho de 1990. Dispõe sobre o Estatuto da Criança e do Adolescente e dá outras providências [Internet]. Brasília; 1990 [citado 2015 fev. 10]. Disponível em: http://www.planalto.gov.br/ccivil_03/leis/l8069.htm

3. Brasil. Ministério da Saúde. Portaria MS/GM n. 737, de 16 de maio de 2001. Política Nacional de Redução da Morbimortalidade por Acidentes e Violências [Internet]. Brasília; 2001 [citado 2015 fev. 10]. Disponível em: http://bvsms.saude.gov.br/bvs/publicacoes/acidentes.pdf

4. Curitiba. Prefeitura Municipal; Fundação de Ação Social. Protocolo da Rede de Proteção à Criança e ao Adolescente em situação de risco para a violência. Curitiba: Secretaria Municipal da Saúde; 2008. 
5. Pasian MS, Faleiros JM, Bazon MR, Lacharité C. Negligência infantil: a modalidade mais recorrente de maus-tratos. Pensando Fam [Internet]. 2013 [citado 2015 fev. 10];17(2):61-70. Disponível em: http://pepsic.bvsalud.org/pdf/penf/v17n2/v17n2a05.pdf

6. DeVerteuil G. Conceptualizing violence for health and medical geography. Soc Sci Med. 2015;133:216-22.

7. Sudbrack R, Manfro PH, Kuhn IM, Carvalho HW, Lara DR. What doesn't kill you makes you stronger and weaker: how childhood trauma relates to temperament traits. J Psychiatr Res. 2015;62:123-9.

8. Guedes RN, Fonseca RMGS. Autonomy as a structural need to face gender violence. Rev Esc Enferm USP [Internet]. 2011 [cited 2015 Feb 10];45(n.spe 2):1730-4. Available from: http://www.scielo.br/pdf/reeusp/v45nspe2/en_16.pdf

9. Fonseca RMGS, Egry EY, Nóbrega CR, Apostólico MR, Oliveira RNG. Recurrence of violence against children in the municipality of Curitiba: a look at gender. Acta Paul Enferm [Internet]. 2012 [cited 2014 May 12];25(6):895-901. Available from: http://www.scielo.br/pdf/ ape/v25n6/en_v25n6a11.pdf

10. Fonseca RMGS. Gênero como categoria para a compreensão e a intervenção no processo saúde-doença. In: Programa de Atualização em Enfermagem na Saúde do Adulto - PROENF. Porto Alegre: Artmed/Panamericana; 2008. p. 9-39.

11. Egry EY. Saúde coletiva: construindo um novo método em enfermagem. São Paulo: Ícone; 1996.

12. Atlas do Desenvolvimento Humano no Brasil. Curitiba, PR [Internet]. Curitiba; 2013 [citado 2015 fev. 10]. Disponível em: http://www. atlasbrasil.org.br/2013/pt/perfil_m/curitiba_pr

13. Instituto Brasileiro de Geografia e Estatística (IBGE). Censo demográfico 2010 [Internet]. Rio de Janeiro: IBGE; 2010 [citado 2014 jan. 15]. Disponível em: http://www.ibge.gov.br/home/estatística/população/censo/2010/

14. Apostólico MR, Nóbrega CR, Guedes RN, Fonseca RMGS, Egry EY. Characteristics of violence against children in a Brazilian Capital. Rev Lat Am Enfermagem [Internet]. 2012 [cited 2014 May 12];20(2):266-73. Available from: http://www.scielo.br/pdf/rlae/v20n2/08.pdf

15. Calheiros MM, Lima ML, Silva C. Extravasamento trabalho-família quando é que as condições de trabalho contribuem para práticas maternas abusivas? Aletheia [Internet]. 2012 [citado 2015 fev. 10];(37):23-41. Disponível em: http://pepsic.bvsalud.org/pdf/aletheia/n37/ n37a03.pdf

16. Fonseca RMGS. Gênero e saúde-doença: uma releitura do processo saúde-doença das mulheres. In: Fernandes RAQ, Narchi NZ, organizadoras. Enfermagem e saúde da mulher. Barueri: Manole; 2013. p. 32-71.

17. Olivi ML, Fonseca RMGS. A mãe sob suspeita: falando da saúde da criança em idade escolar. Rev Esc Enferm USP. 2007;41(2):213-21.

18. Nunes CB, Sarti CA, Ohara CVS. Health care professionals' approaches to address family violence against children and teenagers. Acta Paul Enferm [Internet]. 2009 [cited 2015 Feb 10];22(n.spe):903-8. Available from: http://www.scielo.br/pdf/ape/v22nspe/en_12.pdf

19. Lima JS, Deslandes SF. A notificação compulsória do abuso sexual contra crianças e adolescentes: uma comparação entre os dispositivos americanos e brasileiros. Interface Comun Saúde Educ. 2011;15(38):819-32.

20. Al-Dabaan R, Newton JT, Asimakopoulou K. Knowledge, attitudes, and experience of dentists living in Saudi Arabia toward child abuse and neglect. Saudi Dent J. 2014;26(3):79-87.

21. Sakata KN, Egry EY, Narchi NZ. National policy for reduction of morbidity and mortality from accidents and violence in Brazil: the alignments to international perspectives. Rev Esc Enferm USP [Internet]. 2014 [cited 2015 Feb 10];48(n.spe 2):197-203. Available from: http:// www.scielo.br/pdf/reeusp/v48nspe2/0080-6234-reeusp-48-nspe2-00197.pdf

22. Vendruscolo TS, Ferriani MGC, Silva MAI. Public care policies for child and adolescent victims of domestic violence. Rev Lat Am Enfermagem [Internet]. 2007 [cited 2015 Feb 10];15(n.spe):812-9. Available from: http://www.scielo.br/pdf/rlae/v15nspe/15.pdf

23. Chaves MMN, Egry EY. Municipal Health Conferences: the organized social movement to create health interventions. Rev Esc Enferm USP [Internet]. 2012 [cited 2015 Feb 10];46(6):1423-30. Available from: http://www.scielo.br/pdf/reeusp/v46n6/en_20.pdf

24. Sarmento MJ. Gerações e alteridade: interrogações a partir da sociologia da infância. Educ Soc [Internet]. 2005 [citado 2015 fev. 10];26(91):361-78. Disponível em: http://www.scielo.br/pdf/es/v26n91/a03v2691.pdf

25. Egry EY, Fonseca RMGS, Oliveira MAC. Ciência, saúde coletiva e enfermagem: destacando as categorias gênero e geração na episteme da práxis. Rev Bras Enferm. 2013;66(n.spe):119-33.

Financial Support: Fundação de Amparo à Pesquisa do Estado de São Paulo (FAPESP), FAPESP Case No. 20122/50.932-1, and Fundação Maria Cecília Souto Vidigal (FMCSV). 